\title{
STUDI DISKRIPTIF PERUBAHAN BUDAYA ORGANISASI KEPERAWATAN
}

\author{
Teguh Anindito \\ STIKES Muhammadiyah Kendal \\ Email: tanindito@yahoo.co.id
}

\begin{abstract}
ABSTRAK
Organisasi yang baik juga mempunyai keteraturan yang baik. Keteraturan sudah melekat dan menjadi kebiasaan yang tanpa disadari menjadi budaya, sehingga membedakan dengan kelompok lainnya. Rumah Sakit Islam Muhammadiyah Kendal mengalami pasang surut masa pimpinan pengelola lembaga. Pimpinan baru membawa perubahan, budaya buruk organisasi harus diubah, utamanya bidang keperawatan. Keperawatan di dalam rumah sakit adalah motor penggerak kehidupan organisasi. Tujuan dari penelitian ini untuk melihat sejauhmana perubahan budaya organisasi terhadap budaya kerja perawat setelah adanya perubahan pimpinan. Penelitian ini merupakan penelitian deskriptif. Pengumpulan data dilaksanakan dalam waktu 1 bulan yaitu sejak tanggal 1-30 November 2012 melalui pengisian kuesioner. Sampel penelitian ini adalah perawat yang bekerja di Rumah Sakit Islam Muhammadiyah Kendal. Berdasarkan kriteria inklusi dan eksklusi, peneliti hanya mengambil 33 orang dari 76 yang telah memiliki masa kerja minimal satu tahun, dan mengalami perubahan pimpinan. Data diolah secara manual menggunakan program excel Dari 33 perawat, menyatakan perhatian pimpinan baik $50 \%$, sedangkan $50 \%$ kurang. Kondisi ini menggambarkan bahwa kelompok perawat membutuhkan supervisi yang lebih inten. Dari data di atas dapat disimpulakan bahwa akibat perubahan organisasi, kinerjanya belum maksimal, koordinasi belum maksimal dan rutin, budaya kerja baru belum terbentuk utuh.
\end{abstract}

Kata kunci: Budaya organisasi, Keperawatan 


\title{
DISCRIPTION STUDY OF NURSING ORGANIZATIONAL CULTURE CHANGE
}

\begin{abstract}
A good organization also has good order. Regularity is inherent and becomes a habit that unwittingly becomes a culture, thus distinguishing it from other groups. Muhammadiyah Kendal Islamic Hospital experienced ups and downs during the leadership of the institution's management. The new leadership brings change, the bad culture of the organization must be changed, especially in the field of nursing. Nursing in the hospital is the driving force of organizational life. The purpose of this study is to see the extent to which organizational culture changes to the work culture of nurses after a change in leadership. Data retrieval using descriptive method. Data were taken from RSI nurses totaling 76 nurses Based on the inclusion and exclusion criteria, the researcher only took 33 people who had had a minimum of one year of service, and experienced a change in leadership. Data processing. This data is processed in manual by using excel programe. Of the 33 nurses, 50\% of the leadership's attention is good, while $50 \%$ is less. This condition illustrates that nurses group need more intention supervision. From the data above, it can be concluded that caused organizational changes, performance has not been maximized, coordination has not been maximized and routine, the new work culture has not been fully formed.
\end{abstract}

Keywords: Organizational culture, Nursing

\section{PENDAHULUAN}

Di dunia ini tidak ada yang abadi tidak berubah, karena yang abadi adalah perubahan itu sendiri. Kalimat itu sering diucapkan oleh para tokoh, utamanya para politisi. Sebuah lembaga dalam gerak apapun bidangnya, jika ingin lebih baik dari status quo yang stagnan, maka harus berbenah diri untuk berubah. Perubahan yang dilakukan kalau perlu dengan mengganti pucuk pimpinan, yang merupakan motor utama penggerak perubahan. Pimpinan yang diberikan tanggung jawab dan mau bertanggung jawab memegang amanahnya, akan merasa mempunyai power yang lebih untuk mengubah keadaan (Rivai \& Mulyadi, 2009).

Pengertian budaya menurut Edward Burnett dalam buku Budaya Organisasi oleh Ndraha, Taliziduhu (2003), budaya mempunyai pengertian bahwa secara teknografis sangat luas 
meliputi ilmu pengetahuan, keyakinan, seni, moral, hukum, adat istiadat, dan berbagai kemampuan dan kebiasaan lainnya yang didapat sebagai anggota masyarakat. Vijay Sathe (1985) mengatakan bahwa budaya adalah seperangkat asumsi atau anggapan yang dianggap penting yang dimiliki bersama oleh anggota masyarakat. Kesmpulannya adalah bahwa budaya adalah suatu cara hidup yang berkembang dan dimiliki bersama oleh sebuah kelompok orang dan diwariskan dari generasi ke generasi.

Budaya organisasi adalah bagaimana cara anggota organisasi belajar berhubungan dengan lingkungan dalam organisasinya maupun keluar, yang merupakan penggabungan dari asumsi, ide, perilaku, cerita, mitos, metafora dan ide lain untuk menentukan apa arti bekerja dalam suatu organisasi (Rivai \& Mulyadi, 2009).

Sebuah organisasi yang baik juga mempunyai keteraturan yang baik dan menjadi status quo. Keteraturan tersebut sudah melekat dan menjadi kebiasaan yang tanpa disadari menjadi budaya, sehingga membedakan kelompok itu dengan kelompok lainnya. Anggota kelompok saling berinteraksi 68 dan tampak berbeda dari cara menyelesaikan apa yang dilakukannya (Rivai \& Mulyadi, 2009).

Budaya organisasi yang baik dapat mempunyai dampak pada organisasi dan anggotanya. Dampaknya diantaranya adalah secara signifikan mempengaruhi prestasi kerja secara ekonomi perusahaan dalam jangka panjang. Dampak kedua adalah, merupakan faktor yang paling penting dalam menentukan sukses tidaknya perusahaan dalam masa mendatang. Apabila sukses terjadi maka akan diikuti dampak ketiga yaitu prestasi keuangan akan menjadi kokoh. Dampak selanjutnya prestasi akan meningkat, meskipun sulit untuk diubah (Rivai dan Mulyadi, 2009).

Membentuk budaya organisasi pada prinsipnya adalah menyatukan setiap karakteristik yang ada. Karakteristik ini akan berkembang secara terus-menerus seperti proses perubahan dalam teori berubah Kurt dan Lewin (Suyanto, 2009) dari kontinum rendah ke tinggi sampai dengan diperoleh gambaran majemuk dari organisasi (Rivai dan Mulyadi, 2009). Perubahan harus terencana, terpimpin, dan setapak demi setapak. Para think 
tank akan ikut merasa diajak dan memiliki organisasi dan lembaga, maka mereka harus dimasukkan dalam proses perencanaan. Pemimpin dalam hal ini menggunakan kepemimpinan partisipatif (Monica, 1998).

Organisasi yang sudah besar dan kuat, mempunyai nilai budaya organisasi sangat dipengaruhi oleh salah satu nilai budaya yang dominan. Budaya dominan ini pada akhirnya akan menjadi budaya inti yang dianut bersama oleh mayoritas anggota (Rivai dan Mulyadi, 2009). Modal dasar menjadi penting dalam hal ini, misalnya rumah sakit Islam, maka sudah pasti sebagian besar karyawan menganut agama Islam. Kemudian karena dimiliki oleh organisasi besar semacam Muhammadiyah, maka yang harus dibentuk adalah budaya Muhammadiyah. Hal inilah yang sedikit sulit diwujudkan, karena simpatisan Muhammadiyah adalah minoritas. Namun hal ini bisa diartikan sebagai anak budaya yang melengkapi budaya dominan tadi.

Jika suatu organisasi tidak memiliki nilai budaya dominan, nilai budaya organisasi sebagai variabel independen akan sangat berkurang. Hal ini terjadi karena tidak akan ada 69 penafsiran yang seragam atas apayang menggambarkan perilaku yang tepat dan tidak tepat. Namun kita juga tidak mungkin mengabaikan realitas, bahwa banyak organisasi mempunyai anak budaya yang dapat mempengaruhi perilaku para anggotanya (Rivai dan Mulyadi, 2009).

Apabila anggota organisasi terkungkung pada budaya organisasi dalam jangka lama. Manajer atau pimpinan organisasi harus melakukan perubahan besar dalam organisasi tersebut. Tekanan dari pihak eksternal atau internal organisasi akan muncul. Biasanya akan terdapat penolakan terhadap perubahan, karena mengubah berarti bisa dianggap menyusahkan dan menambah pekerjaan, mengubah kebiasaan dan status quo yang sudah ada. Organisasi dapat melakukan perubahan tujuan dan strategi, teknologi, desain jabatan, struktur, proses dan orang-orangnya atau anggotanya.

Perubahan yang dikembangkan Kurt Lewin bermanfaat untuk menguji variabel guna menentukan tingkat efektifitas suatu perubahan budaya organisasi. Analisis yang dilakukan mencakup empat tingkat perubahan organisasional yaitu perubahan 
pengetahuan, sikap, perilaku organisasional, dan perubahan prestasi kelompok atau organisasional. Tingkatan perubahan tersebut saangat signifikan dalam perubahan partisipatif dan perubahan yang direksional. Perubahan tersebut tetap harus mengikuti langkah melelehkan budaya lama, melakukan gerakan ke keadaan baru dan kemudian memantapkan suatu intervensi perubahan dengan mempertimbangkan kekuatan dorong dan kekuatan penahan (Rivai dan Mulyadi, 2009).

\section{Rumah Sakit Islam}

Muhammadiyah Kendal mengalami pasang surut masa sukses dan tidaknya pimpinan mengelola lembaga Amal Usaha Muhammadiyah. Kesuksesan itu tidak hanya dilihat dari jumlah pasien yang masuk, tetapi juga dari keteraturan dan sisa hasil usaha yang dilaporkan secara jujur dan teratur sebagai wujud adaptasi terhadap unsur eksternal, dalam hal ini yayasan (Tika, 2010). Sadar akan kewajiban, bahwa dia adalah bagian dari lembaga, bukan pemilik lembaga. Pimpinan harus melaporkan hasil kerjanya secara teratur dan berkesinambungan.

Rumah Sakit Islam

Muhammadiyah Kendal sebelumnya 70 mengalami fase penurunan keteraturan di atas, sehingga organisasi berjalan dengan seadanya dan asal jalan. Pelaporan dengan lembaga di atasnya yang mewakili Muhammadiyah sebagai pemilik menjadi tidak dilakukan. Komunikasi terhambat, karena adanya keengganan pihak pimpinan yang merasa terancam jabatannya. Pimpinan merasa sudah waktunya diganti bukan tanpa sebab, karena dirinya merasa tidak bisa memenuhi target yang dibebankan. Penggantian adalah sebuah konsekuensi atau akibat.

Status quo dalam hal budaya buruk organisasi harus diubah, utamanya bidang keperawatan. Keperawatan di dalam rumah sakit adalah motor penggerak kehidupan organisasi. Keperawatan stagnan, maka rumah sakit akan mati suri. Kepemimpinan dalam bidang keperawatan sekarang menjadi lebih baik. Pimpinan rumah sakit telah membuat kebijakan dengan memberi status lebih tinggi dalam struktur organisasi rumah sakit. Keperawatan yang tadinya paling tinggi hanya Seksi Keperawatan non job, karena tidak punya kantor khusus, tidak punya jabatan struktural, apalagi tunjangan. Status itu menjadi lebih baik, karena 
sekarang ada kantornya, ada jabatan struktural setingkat Kepala Bagian yang membawahi Kepala Seksi Etika, Mutu dan Askep dan Kepala Seksi Ketenagaan dan Fasilitas Keperawatan.

Data awal yang didapat dari Kepala Bagian Keperawatan didapatkan data sementara bahwa efektifitas pengorganisasian keperawatan baru berjalan 50 \%. Kepala Seksi Etika dan Mutu Asuhan Keperawatan mengatakan asuhan keperawatan dokumentasinya sudah berjalan $90 \%$, efektifitas pengorganisasian keperawatan sudah dijalankan $65-70 \%$, sedangkan SOP yang baru, bisa dilakukan sekitar 40$50 \%$. Sebagai pembanding, penulis bertanya kepada Kepala Bagian Personalia, kinerja personalia sesuai struktur organisasi keperawatan baru berjalan efektif $30-40 \%$.

Perubahan organisasi yang dilakukan, berakibat budaya organisasi juga harus berubah karena perubahan harus dijemput dengan mengubah diri. Perubahan bisa dilakukan secara bertahap, baik secara keseluruhan manajemen organisasi keperawatan, maupun dari tahapannya (Rivai \& Mulyadi, 2009). Penulis memotret perubahan budaya organisasi dalam proses perencanaan, sedikit pelaksanaan dan evaluasi.

Perubahan budaya organisasi dan kinerja dari struktur organisasi baru keperawatan, akan diukur dari hasil pemberian kuesioner kepada staf keperawatan yang ada di ruang rawat inap. Jawaban kuesioner tersebut akan menghasilkan data sejauhmana struktur organisasi keperawatan baru mengubah diri, membentuk budaya organisasi yang baru. Perawat yang diberi kuesioner adalah perawat yang bekerja minimal satu tahun, karena mengetahui peristiwa perubahan dari sebelumnya ke yang sekarang. Data yang diambil oleh penulis adalah sebagaimana tujuan perencanaan yang baik, maka yang akan ditanyakan adalah berbagai hal dalam proses perencanaan yang dapat mengubah budaya organisasi.

Pengambilan data dalam karya ilmiah ini bertujuan untuk mengetahui perubahan budaya organisasi setelah terbentuknya struktur organisasi keperawatan baru. Apakah dalam melakukan asuhan keperawatan di Ruang Rawat Inap Rumah Sakit Islam Muhammadiyah Kendal tahun 2010 kinerja dan budaya kerjanya berubah ?. 
Penelitian ini merupakan
penelitian deskriptif Pengumpulan data
dilaksanakan dalam waktu 1 bulan yaitu
sejak tanggal ....... melalui pengisian
kuesioner. Sampel penelitian ini adalah
perawat yang bekerja di Rumah Sakit
Islam Muhammadiyah Kendal.

Berdasarkan kriteria inklusi dan eksklusi, peneliti hanya mengambil 33 orang perawat dari sejumlah 86 orang perawat yang ada. Perawat tersebut telah memiliki masa kerja minimal satu tahun. Kriteria ini diambil karena telah mengalami masa perubahan dari organisasi lama ke organisasi baru. Data ini diolah dengan menggunakan excel.

\section{HASIL DAN PEMBAHASAN}

Hasil pendataan yang dilakukan penulis tampilkan dalam tabel di bawah ini:

Tabel: Perubahan Budaya Organisasi Terhadap Budaya Kerja Perawat

\begin{tabular}{|c|c|c|c|}
\hline \multirow{2}{*}{ No } & \multirow{2}{*}{ Variabel } & \multicolumn{2}{|c|}{$\%$} \\
\hline & & Ya/baik & Tdk/kurang \\
\hline 1 & $\begin{array}{l}\text { Perubahan } \\
\text { budaya }\end{array}$ & 80 & 20 \\
\hline 2 & $\begin{array}{l}\text { Perubahan } \\
\text { organisasi }\end{array}$ & 100 & 0 \\
\hline 3 & Dampak & 90 & 10 \\
\hline 4 & $\begin{array}{l}\text { Kesesuaian visi } \\
\text { misi }\end{array}$ & 100 & 0 \\
\hline 5 & $\begin{array}{l}\text { Perubahan } \\
\text { koping efektif }\end{array}$ & 80 & 20 \\
\hline 6 & Pengorganisasian & 80 & 20 \\
\hline 72 & & & \\
\hline
\end{tabular}

\begin{tabular}{clcc}
7 & $\begin{array}{l}\text { Akomodasi } \\
\text { kepentingan }\end{array}$ & 80 & 20 \\
8 & $\begin{array}{l}\text { Mutu yang } \\
\text { dihasilkan }\end{array}$ & 80 & 20 \\
\hline 9 & $\begin{array}{l}\text { Koordinasi } \\
\text { pimpinan }\end{array}$ & 100 & 0 \\
\hline 10 & $\begin{array}{l}\text { Koordinasi } \\
\text { Ruangan } \\
11\end{array}$ & 60 & 40 \\
$\begin{array}{l}\text { Perhatian } \\
\text { pimpinan }\end{array}$ & 50 & 50 \\
\hline 12 & $\begin{array}{l}\text { Kerjasama } \\
\text { bawahan }\end{array}$ & 100 & 0 \\
\hline 13 & $\begin{array}{l}\text { SOP perubahan } \\
\text { Pengawasan }\end{array}$ & 70 & 30 \\
\hline 14 & $\begin{array}{l}\text { Peningkatan } \\
\text { pengetahuan }\end{array}$ & 90 & 50 \\
\hline 16 & Kinerja & 10 \\
\hline
\end{tabular}

Hasil pendataan yang dilakukan penulis dibahas seperti di bawah ini :

\section{A. Budaya Organisasi}

Sebagian besar responden sejumlah $\quad 80 \quad \% \quad$ dari $\quad$ staf keperawatan di ruangan mengatakan, bahwa perubahan budaya ini membawa akibat baik. Hasil perubahan adalah peningkatan kinerja dan disiplin. Pimpinan rumah sakit perlu untuk membentuk ciri yang membedakan dengan rumah sakit lain agar tetap dibutuhkan oleh masyarakat (Rivai dan Mulyadi, 2009).

\section{B. Perubahan Organisasi}

Hasil survey menunjukkan bahwa semua staf keperawatan (100 \%) setuju dengan adanya 
perubahan ini, berarti perbaikan dan perubahan budaya disetujui tidak hanya oleh pimpinan, tetapi semua staf mendukungnya. Perubahan memang harus perlahan, karena perubahan tersebut tetap harus mengikuti langkah melelehkan budaya lama, melakukan gerakan ke keadaan baru dan kemudian memantapkan suatu intervensi perubahan dengan mempertimbangkan kekuatan dorong dan kekuatan penahan (Rivai dan Mulyadi, 2009).

\section{Dampak Perubahan}

Sebagain besar staf keperawatan sejumlah $90 \%$ mengatakan, bahwa perubahan berdampak signifikan terhadap perubahan kinerja staf keperawatan dalam bekerja. Perubahan dalam jangka panjang dapat mempengaruhi prestasi kerja dan secara ekonomi (Rivai dan Mulyadi, 2009). Perubahan belum tampak dari kinerja yang keluar dari rutinitas saja, menuju kreatifitas dan modifikasi serta sesuai Standar Operasional Prosedur. Hasil survey dari laporan Pelaksanaan Program Kerja Tahun 2010 menunjukkan BOR dan Sisa Hasil Usaha meningkat signifikan.
D. Kesesuaian Perubahan dengan Visi Misi Rumah Sakit

Staf keperawatan secara keseluruhn sejumlah $100 \quad \%$ mengatakan, bahwa perubahan yang dilakukan telah sesuai dengan visi misi rumah sakit dari keseluruhan responden. Ciri atau perbedaan yang khas dari organisasi perlu dibentuk agar membedakan dengan organisasi lain (Rivai dan Mulyadi, 2009). Pengarahan, integrasi dan perhatian, untuk mengajak karyawan diharapkan memerhatikan presisi, kecermatan dan analisis untuk mencapai sasaran dan tujuan dalam organisasi, sesuai visi dan misi dan tujuan organisasi (Rivai dan Mulyadi, 2009)(Tika, 2010).

\section{E. Perubahan Memberi Koping Efektif}

Dikatakan oleh $80 \%$ responden, bahwa perubahan memberikan koping yang efektif dalam situasi kritis mengatasi masalah. Keterlibatan atasan dalam hal ini struktural keperawatan di atasnya belum ikut terjun menangani 
masalah. Responden yang mengatakan belum memberi koping efektif, memang jumlahnya $20 \%$ saja. Staf keperawatan harus memperhatikannangka ini. Masalah yang penting seharusnya mendapat prioritas meskipun ada kepala ruangan yang memimpin tiap ruangan. Budaya organisasi yang kuat adalah apabila kekuatan budaya telah mempengaruhi intensitas perilaku (Sathe,1985). Tiga ciri dari budaya yang telah mempengaruhi perilaku adalah thickness, extent of sharing dan clarity of ordering (ketebalan, tingkat berbagi dan kejelasan pemesanan). Membentuk budaya organisasi pada prinsipnya adalah menyatukan setiap karakteristik yang ada. Karakteristik ini akan berkembang secara terus-menerus seperti proses perubahan dalam teori berubah Kurt dan Lewin (Suyanto, 2009) dari kontinum rendah ke tinggi sampai dengan diperoleh gambaran majemuk dari organisasi (Rivai dan Mulyadi, 2009).

\section{F. Pengorganisasian Perubahan}

Data menunjukkan bahwa $80 \%$ responden mengatakan bahwa perubahan belum sepenuhnya diorganisasikan dengan baik. Menurut bidang keperawatan, saat ini setelah reorganisasi, pejabat struktural sedang disibukkan dengan persiapan akreditasi rumah sakit. Hal ini menunjukkan bahwa para pejabat masih belum bisa membuat skala prioritas yang baik. Perubahan harus terencana, terpimpin, dan setapak demi setapak. Para think tank akan ikut merasa diajak dan memiliki organisasi dan lembaga, maka mereka harus dimasukkan dalam proses perencanaan. Pemimpin sebaiknya menggunakan kepemimpinan partisipatif (Monica, 1998).

\section{G. Akomodasi Kepentingan}

Responden berjumlah $80 \quad \%$ mengatakan bahwa perubahan mengakomodasi kepentingan dan aspirasi bawahan. Angka $20 \%$ yang mengatakan aspirasi belum diserap oleh pejabat struktural keperawatan menunjukkan staf keperawatan belum maksimal menyerap aspirasi bawahan. 
Komunikasi dan desiminasi atau sosialisasi menjadi bagian yang sangat penting sebelum proses perubahan yang dilakukan agar tidak terjadi konflik organisasi. Keberhasilan intervensi perubahan budaya organisasional akan dipengaruhi empat hal yaitu karakteristik organisasi, karakteristik intervensi, proses sosilaisasi dan indikator proses sosialisasi (Rivai dan Mulyadi, 2009). Maka sosilisasi yang beradab, mudah diterima dan dianggap menguntungkan, misalnya ada janji perubahan ke arah lebih baik, penghasilan lebih banyak dan sebagainya sangat penting diperhatikan.

\section{H. Mutu}

Responden sejumlah $\quad 80 \quad \%$ mengatakan bahwa penyerapan aspirasi ini berdampak positif terhadap kinerja berupa peningkatan mutu dan terjalinnya hubungan timbal balik atasan dan bawahan. Pengarahan, integrasi dan perhatian, yaitu sejauhmana karyawan diharapkan memerhatikan presisi, kecermatan dan analisis untuk mencapai sasaran dan tujuan dalam organisasi penting untuk dilakukan (Rivai dan Mulyadi, 2009)(Tika, 2010).

\section{Koordinasi}

Responden semua $\quad(100 \%)$ menjawab bahwa perubahan budaya organisasi telah membuat adanya kegiatan rutin berupa koordinasi yang berdampak positif pada peningkatan pengetahuan dan keterampilan dalam kegiatan asuhan keperawatan. Koordinasi ini biasanya diisi dengan penambahan materi dan desiminasi hasil seminar di tempat lain oleh petugas yang mengikutinya. Pengarahan, integrasi dan perhatian, dalam koordinasi untuk mengajak karyawan memerhatikan presisi, kecermatan dan analisis untuk mencapai sasaran dan tujuan dalam organisasi, sesuai visi dan misi dan tujuan organisasi penting untuk dilakukan secara rutin dan terencana (Rivai dan Mulyadi, 2009)(Tika, 2010).

\section{J. Koordinasi Ruangan}

Responden sejumlah $40 \%$, menjawab bahwa perubahan budaya organisasi yang dilakukan belum berdampak pada adanya 
rapat rutin di ruangan. Koordinasi dilakukan di ruangan tertentu hanya saat diperlukan saja (30 \%). Koordinasi penting dilakukan untuk perencanaan yang matang, mengatasi masalah dan sebagai evaluasi sementara apakah tujuan organisasi tercapai (Rivai dan Mulyadi, 2009)

\section{K. Perhatian Pimpinan kepada Bawahan}

Data menunjukkan bahwa $50 \%$ responden menjawab, bahwa perubahan telah membawa dampak perhatian pimpinan kepada bawahan secara intensif, tetapi masih $50 \%$ pimpinan yang tidak melakukannya. Hasil ini juga sesuai dengan jawaban mengenai kurangnya koordinasi ruangan. Hasil ini menunjukkan bahwa, pejabat struktural harus menginstruksikan peningkatan frekuensi pertemuan atau koordinasi di ruangan berupa pre atau post conference. Pola kinerja komunikasi, yaitu sejauhmana komunikasi dibatasi oleh hirarki yang formal. Pola komunikasi yang tidak tepat dapat menghambat terjadinya komunikasi antara bawahan dan atasan. Pola kinerja komunikasi itu dapat berupa komunikasi personal ritual yaitu yang dilaksanakan secara pribadi. Pola kounikasi sosial ritual, yaitu yang dilakukan secara bersamasama, namun tidak berkaitan dengan pekerjaan. Dan pola komunikasi kinerja organisasional ritual, yaitu kebiasaan yang diikuti oleh kelompok organisasi secara teratur (Tika, 2010).

\section{Ajakan Kerjasama oleh Pimpinan}

Responden semuanya (100 \%) merasa telah diajak untuk bekerjasama. Perubahan, meskipun data kontradiktif dengan penyerapan aspirasi yang dianggap belum menyerap sebagian aspirasi, tetapi menunjukkan bawahan sebagian besar sudah diajak kerjasama dalam mencapai tujuan. Agresifitas pimpinan dalam mengajak bawahan untuk aktif bekerja mengubah kinerja agaknya penting ditingkatkan agar semakin kompetitif dan energinya dapat disalurkan untuk meningkatkan nilai kerja (Rivai\&Mulyadi, 2009). 


\section{Pembuatan SOP}

Sejumlah $\quad 70 \quad \% \quad$ responden mengatakan. Standar Operasional Prosedur setelah perubahan belum dibuat dan dilaksanakan secara sepenuhnya. SOP sangat diperlukan agar memberi ciri dan pembiasaan budaya dalam melakukan ashuan keperawatan kepeda pasien. Data di atas memerlukan tindak lanjut. SOP bila tidak ada pengembangan akan mengarahkan pada status quo dan memungkinkan tidak ada perubahan tetapi komitmen bersama akan membuat SOP yang dinamis dan bernilai (Rivai \& Mulyadi, 2009).

\section{N. Rutinitas Pengawasan}

Responden yang merasa diawasi sebanayak $50 \%$. Pengarahan dan pengawasan oleh pejabat struktural setelah perubahan belum ada tindakan nyata menyeluruh di awal dan akhir kegiatan organisasi. Pembuatan mekanisme kendali yang memandu dan mengawasi dalam supervisi serta membentuk sikap dan perilaku karyawan penting untuk dilakukan (Rivai \& Mulyadi, 2009).

\section{O. Peningkatan Pengetahuan}

Sejumlah $\quad 90 \% \quad$ responden menjawab, kegiatan pertemuan untuk peningkatan pengetahuan sudah dilaksanakan karena menurut teori tingkat perubahan dari Hershey dan Blanchard (1977) dalam Rivai \& Mulyadi, (2009) dikatakan bahwa pengetahuan dapat mengubah sikap, sikap dapat mengubah perilaku individu dan akhirnya adanya perubahan pada kelompok.

\section{P. Kinerja}

Responden yaitu $20 \quad \% \quad$ staf keperawatan di ruangan masih merasa kurang dengan kinerjanya, karena yang merasa sudah baik kinerjanya $60 \%$ saja, hal ini berarti dorongan dan semangat memacu mereka masih perlu dilakukan. Perawat yang menjawab kinerjanya belum baik ada $30 \%$. Pemberian motivasi bisa dilakukan misalnya dengan perhatian pimpinan, reward rutin biasanya tahunan, kenaikan pangkat istimewa dan lainnya yang mendorong terjadinya peningkatan komitmen. Perubahan dalam jangka panjang dapat mempengaruhi 
prestasi kerja dan secara ekonomi (Rivai dan Mulyadi, 2009).

\section{KESIMPULAN}

Ciri yang membedakan budaya organisasi rumah sakit ini dengan rumah sakit lain belum tampak, atau masih sebatas konsep, sehingga perlu dirumuskan oleh kelompok kerja keperawatan.

Perubahan budaya organisasi di Rumah sakit Islam Muhammadiyah Kendal sudah berdampak positif pada berbagai hal, termasuk kesejahteraan, tetapi masih perlu perbaikan. Perbaikan yang perlu adalah pada penyerapan aspirasi, koordinasi, dan pengawasan serta pemberian motivasi untuk peningkatan kinerja.

Pembuatan Standar Operasional Prosedur yang sesuai visi misi yang mendorong perubahan menuju ciri yang membedakan belum selesai dilaksanakan.

Perlu segera dibentuk Kelompok Kerja Keperawatan yang merumuskan ciri yang diinginkan sesuai visi misi rumah sakit
Pihak pimpinan baik dari Direktur, Wadir SDM dan Pelayanan penting untuk mensupervisi dan mendorong pimpinan dan staf keperawatan agar bisa lebih optimal memanfaatkan waktunya dengan menggunakan skala prioritas. Misalnya membantu staf dalam mengatasi masalah di ruangan, meminta kepala ruangan berkoordinasi rutin, menyerap aspirasi bawahan dengan supervisi, pengarahan dan pengawasan yang adil dan bermartabat

Standar Operasional Prosedur penting untuk segera diselesaikan yaitu berciri Islami.

\section{UCAPAN TERIMAKASIH}

Ucapan terima kasih penulis sampaikan kepada Direktur dan staf keperawatan RSIM yang telah mendukung proses pengambilan data. Isteri dan anak penulis juga berperan mendampingi ketika pendataan dilakukan.

\section{DAFTAR PUSTAKA}

Gillies, (1996) Manajemen keperawatan : suatu pendekatan sistem, edisi ke dua. Philadelphia : W.B Saunders Company. 
Marquis, B. L. \& Hustons, C. J. (1996). Leadership roles and managemen function in nursing : theory \& application. $2^{\text {nd }}$ ed. Lippincott.

Monica, Elaine L.La (1998) Kepemimpinan dan manajemen keperawatan, Jakarta:EGC

Nursalam, (2002). Manajemen keperawatan : aplikasi dalam praktik keperawatan profesional. Jakarta : Salemba Medika.

Ndraha, Taliziduhu. (2003). Budaya organisasi, Jakarta : PT. Asdi Mahasatya.

Potter \& Perry. (2005). Fundamental keperawatan : konsep, proses dan praktik. Jakarta : EGC

Rivai, Veithzal dan Mulyadi, Deddy. (2009) Kepemimpinan dan perilaku organisasi, Jakarta: Rajawali Pres

Sathe, Vijay. (1985). Culture and Related Corporate Realities, Richard D Irwin, Inc. Homewood,III

Suarli, Bahtiar. (2009). Manajemen Keperawatan dengan Pendekatan Praktis. Jakarta : Erlangga.

Suyanto. (2009). Mengenal Kepemimpinan dan Manajemen Keperawatan Di. Rumah Sakit. Jogjakarta : Mitra Cendekia Press.

Tika, Moh Pabundu. (2010). Budaya Organisasi dan peningkatan Kinerja Perusahaan. Jakarta: Bumi Aksara 